\title{
Landslide hazard zonation, mapping and investigation of triggering factors in Phewa lake watershed, Nepal
}

\author{
P. Basnet ${ }^{1 *}$, M. K. Balla ${ }^{1}$ and B. M. Pradhan ${ }^{1}$
}

\begin{abstract}
The landslide triggering factors were investigated followed by the thematic maps and landslide distribution map prepared and classified using the GPS and GIS Softwares like CartaLinx, ArcView and ERDAS IMAGINE in Sarangkot and Kaskikot Village Development Committees, Kaski district. In analytical hierarchy process, the factors for zonation were compared by Couple Comparison Method and their weights were determined using Arithmetic Mean Method and earned weight values of each factor. The landslide hazard zonation model was employed to prepare landslide hazard zonation map of the study area, and then classified into five relative hazard classes using the equal interval classification method. Finally, the landslide hazard zonation map was crossed with the landslide distribution map and the model applicability was confirmed by determining the per hazard class percent of area covered by the landslide. In the land hazard zonation map, $0.44 \%$ of the study area was in very low hazard, $2.11 \%$ in low hazard, $54.92 \%$ in moderate hazard, $21.34 \%$ in high hazard and $21.19 \%$ in very high hazard area. The major portion of the study area was on the moderate zone whereas the least portion was on the very low hazard zone. In the study area, most of the high and very high hazard class areas were found occupying the areas closer to the linear triggering factors like presence of linement and fault, presence of motorable road and presence of rivers and streams. The landslide density of the study area was found to be 0.44 per $\mathrm{km}^{2}$ indicating the higher hazard susceptibility of the area.
\end{abstract}

Key words: Landslide, hazard zonation, analytical hierarchy process, fault, geographic information system, global positioning system, linement

\begin{abstract}
$\mathrm{A}^{1}$ landslide also referred to as mass movement, slope failures, slope instability, and terrain instability is the mass movement, usually sudden, of soil and debris down a steep slope (Cruden, 1991). They are caused by a variety of factors such as heavy rains, earthquake ground shaking or geological forces. Different types of landslides move down slope at a wide range of speeds (Varnes, 1978). Most of the terrain in the mountainous areas has been generally subjected to slope failure under the influence of a variety of causal factors and triggered by events such as earthquake or extreme rainfall (HMG/N,1999). Heavy rainfall and ground water on the hills saturate rocks and soil that decreases shear strength. These phenomena not only cause loss of life and property, they also pose severe threats to physical infrastructure, lake and disrupt social and economic development (Pradhan, 2007). The more rapidly moving landslides may pose a greater hazard to life because they can destroy dwellings or damage roads quickly and with little warning.
\end{abstract}

Institute of Forestry, Pokhara, Nepal

*Corresponding author: prakash.nature@gmail.com
Slower moving landslides will gradually cause increasing amounts of damage, but the expected movement can be anticipated (UNDRO, 1991). Several landslides occur every year in Himalayan region; damage caused by landslides is estimated to cost more than US $\$ 1$ billion in economic losses and landslides cause more than 200 deaths every year (Pradhan, 2007).

Main factors responsible for triggering the landslide are lithology (rock type), slope, fault, land use, presence of motorable road, presence of rivers, streams, and aspect. Geologically, the high and very high hazard class areas are primarily associated with surfacial deposit, southward aspect and the linear triggering factors like presence of fault, motorable road and river and streams, and indiscriminate soil quarrying (Maharjan, 2006, and Poudel et al., 2006). Steep slopes, topographical variation and geological characteristics, together with torrential rain during the monsoon season, the country frequently experiences landslides and debris flows that result 
floods in downstream location. The landslides and resulted floods, is thought to contribute to an annual soil loss of 20-25 t/ha (JICA, 2001). The frequency and the magnitude of slope failures can increase due to human activities such as deforestation, cultivation in marginal lands or urban expansion. Landuse such as shrublands, grasslands and valley cultivation lands are more hazardous compared to level terrace, forest and sand/gravel/boulders areas (Maharjan, 2006). The Mahabharat range of Nepal have rugged mountains topography, complex and fragile nature of the geological formations and soft soil cover, high intensity rainfall in the monsoon season, deforestation, surcharge loads of vegetation and frequent earthquakes, the mountains are thus vulnerable to the landslides (Upreti, 1996).

The zonation of landslide hazard may be the basis for any landslide disaster mitigation work and can supply planner and decision-makers with adequate and understandable information (HMG/N, 1999). Landslide hazard analysis is a complex task. It requires large number of input parameters and techniques for analysis. The process involves both cost and time (Tianchi, 1996).

Geographic Information System (GIS) is a powerful set of tools for collecting, retrieving at will, transforming, and displaying spatial data from the real world for a particular set of purposes can help overcome this problem Burrough (1986). Since the landslide hazard zonation is very much related to spatial information e.g. topography, geology, land cover, rainfall, etc, GIS can be effective in analyzing these factors at various location of a given area. It is also possible in GIS to make digital representation of the topography of the area which is very useful for the analysis of landslide hazard and their zonation (Lan et al, 2004).

\section{Materials and methods}

\section{Study area}

The study was carried out in two Village Development Committees (VDCs) namely; Sarangkot and Kaskikot of Phewa watershed (which spans an area of $123 \mathrm{~km}^{2}$ ) located in Kaski district. Those VDCs occupy an area of $42.68 \mathrm{~km}^{2}$ lying at the heart of the Phewa watershed. The location map of the study area is presented in figure 1.

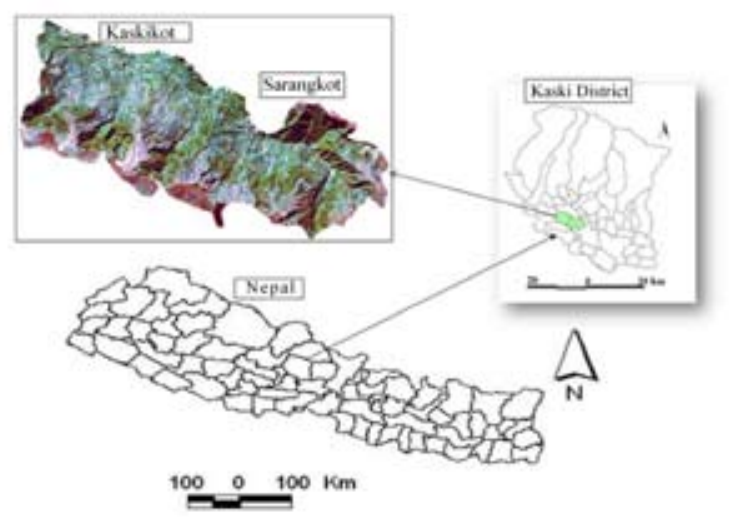

Fig.1: Location of study area (Source: DDC, Kaski, 2010)

Major land uses in the study area are forests, agriculture land, grasslands, valley cultivation, shrub lands and sand/gravel/boulder areas. Among these, forest covers the maximum percentage of the area. The rugged terrain is drained by a number of streams and rivers among which Harpan Khola draining into Phewa lake is the major one (DDC, 2010). The drainage pattern of the watershed is dendritic. Geologically, most of the area falls under the fragile lesser Himalayan Meta-sedimentary zone with discontinuities in covering rock strata, folding, faulting and intense monsoon rainfall events, landslides, soil erosion, rural road construction and sedimentation in upstream and downstream location especially in Phewa lake are the major causes of land degradation. It includes the rock types of Kunchha formation along with the rocks of Ghachok formation and the Non Active Alluvial Fan Deposits. The majority of area falls under the dip angle class ranging from $20^{\circ}$ to $45^{\circ}$ (Engineering and Environmental Geological Map of Pokhara Valley, 2003).

\section{Data collection}

For capturing the data in digital format topographic maps $(1: 25,000)$ of 1998 and 1999, geological map $(1: 50,000)$ of 2003 , satellite image of Phewa watershed of 2009 and meteorological data (Paudur Meteorological Station 2000 to 2009, Kaski) were used and analyzed with the geographic information system (GIS) software (CartaLinx , Arc View, Arc View Spatial Analyst and ERDAS IMAGINE). Global positioning system (GPS) was used for boundary survey of landslides, Abney's Level for measurement of the slope of the landslide area and Silva Compass for determination of the aspect, dip and strike of the rock beds for field data collection. 
A preliminary survey, with the assistance of the local people was carried out to select the existing active landslides. Key informant interview (KII) and morphometric study of the landslides was carried out during boundary survey. The morphometric data of the landslide includes the location of landslides, lithological structure, vegetation cover, type of land use around the landslides, slope, road construction, river and water ways, altitude, aspect, etc.

\section{Data analysis}

The geographic location data of landslide boundary was downloaded to prepare digital landslide distribution map, which was then converted to grid for the spatial analysis. To investigate triggering factors, different factor maps (rainfall, rock type, slope, fault, landuse, motorable road, rivers and streams and aspect) were prepared using the GIS software and relational analysis was carried out.

The area (i.e. number of the grids) of the landslide in a particular class of each of factor maps was determined by using the histogram by zones function in the ArcView Spatial Analyst. After the number of the grids of landslide area in a particular class was determined, the percentage of area of the factor class covered by landslide area for each factor class of the different factors was computed by simple mathematical calculation. And, subjective relational analysis between the percentages of area covered by landslide and the factor classes carried out. The particular factor was considered as the actual triggering factor, if there was relation between the factor classes and the percentages of landslide covered area.

\section{Zonation using analytical hierarchy process (AHP)}

Satty (1980) developed the AHP to standardize the multi-factor decision-making process. AHP provides a hierarchical structure by reducing multiple variable decisions into a series of couple/pair comparisons and develops subjective priorities based upon the user's judgment. While applying AHP, factors were compared with each other to determine the relative preference of each factor in accomplishing the overall goal and numerical values were assigned to each pair using the guidelines established in Fundamental Satty's Scale. Preference of one factor was compared with other and if two factors contribute the landslide equally (equally preferred) then giving the numerical value 1 . If experience and judgment slightly favour one factor over another results the value 3, strongly preferred giving value 5 , very strongly preferred giving value 7 , extremely preferred giving value 9 , and the intervals between preferences is compromise between two factors is needed then giving 2, 4, 6 and 8 . If a factor has one of the above numerical values assigned to it when compared with another factor, then the second factor has the reciprocal value when compared with the first factor results reciprocal of above numerical values.

\section{Couple Comparison of the triggering factors and their prioritization based on their derived weight values}

The couple comparison method was used to determine the preference of the triggering factors. The factors identified as the actual triggering factors in the above step was arranged in the form of the matrix and were subjectively compared with each other as a couple and their preference was expressed in the numeric values in the adjacent cells i.e. the factors preferences were quantified. Once the preferences determined, alternative weight of the couple comparison matrix was calculated using arithmetic mean method. In this method, values of each column of couple comparison matrix were summed up. Then values in each cell of the matrix was divided by the summed value of the same factor column, and the factor mean values were derived in each row as mean of the values in each row. These mean values of each row are the weight values ('w') of each factor.

\section{Weight values to each factors class}

The weight values from 0-100 (let us say ' $m$ ' values) were given to each class of factors on the basis of the percentages of area covered by the landslide area in each of them. The class of each factor having the maximum percentage of area covered by the landslide area was given the maximum value i.e. 100 and the class having the minimum coverage was given the minimum value i.e. 0 and then other classes whose coverage was in-between them was given a intermediate values on proportional basis.

For investigating the triggering factors and zonation of landslide hazard method employed by Esmali (2003) was used,

Landslide hazard zonation model for the zonation 
of the watershed:

$\mathrm{M}=\mathrm{w} 1 * \mathrm{x} 1+\mathrm{w} 2 * \mathrm{x} 2+$

Where,

$\mathrm{M}=$ cumulative weight value = susceptibility Coefficient

$\mathrm{x} 1, \mathrm{x} 2 \ldots=$ ' $\mathrm{m}$ ' values related to the triggering factors $\mathrm{x} 1, \mathrm{x} 2 \ldots$ and

$\mathrm{w} 1, \mathrm{w} 2 \ldots=$ weight values related to $\mathrm{x} 1, \mathrm{x} 2 \ldots$ factors

Based on the calculated susceptibility coefficient, the study area was classified into 5 classes of hazard zones: $M \leq 30$ : very low hazard; $M=30-45$ : low hazard; $M=45-62$ : medium hazard; $M=62-89$ : high hazard and $M \geq 89$ : very high hazard. Finally, the landslide hazard zonation (LHZ) map of the study area was prepared using AHP method. The map was further analyzed using the histogram by zones Function in the ArcView Spatial Analyst and the hazard susceptibility conditions of the different classes of the different triggering factors were computed.

\section{Results and discussion}

A total of 16 landslides were found located at different parts of the study area. The overall landslide density in the study area was found to be 0.44 per $\mathrm{km}^{2}$. Out of 16 landslides, nine were located in Sarangkot VDC and seven in Kaskikot VDC (Table 1). The largest $\left(95,312 \mathrm{~m}^{2}\right)$ landslide was located in Sarangkot VDC, whereas the smallest $\left(160 \mathrm{~m}^{2}\right)$ landslide was at Kaskikot VDC.

The final landslide distribution map prepared by combining the landslide digitized from the topographical map and the boundary survey data collected by GPS is given in figure 2 .

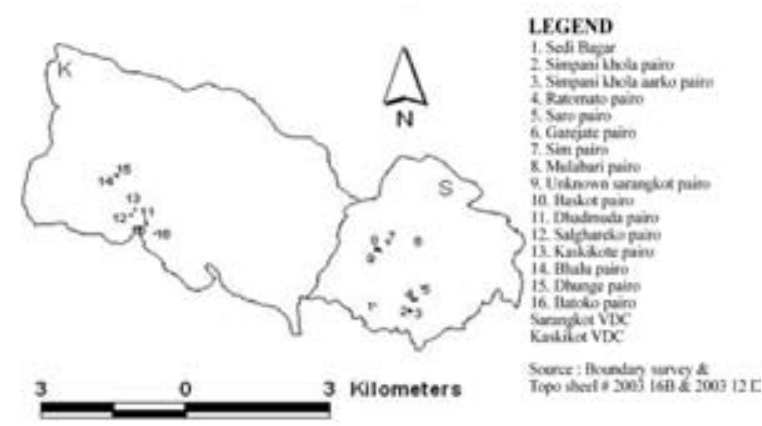

\section{Factors triggering landslide occurrences}

From the analysis it was found that percentage area covered by landslide varied with the variation in the rock type, land use and aspect, increased with the increase in the slope and decreased with the increase in the distance from the features like road, rivers and streams, linement and fault. Thus, eight factors i.e. lithology, land use, linement and fault, rainfall, slope, aspect, road and stream were identified as the actual factors triggering the landslide in the study area and considered for the LHZ map preparation.

\section{Preferences and weight values of the triggering factors}

The pair wise comparison between the factors on the vertical column and the factors on the horizontal row are presented and the preferences of the factors are shown in their corresponding intersecting cells in table 2. When the factor lithology was compared with the horizontal row factors, lithology being the same in column and row hence, equally preferred. Therefore, the cell was assigned the numerical value 1, meaning that the two factors in the vertical column i.e. lithology and horizontal row i.e. lithology are equally preferred. Similarly, the factor in the vertical column i.e. lithology when compared with the factor aspect in the horizontal row, the rock type factor was judged to be extremely preferred over the aspect factor, thus cell was assigned the numerical value 9 meaning that the lithology factor in the vertical column was extremely preferred in comparison to the aspect factor in the horizontal row. In the similar fashion all the cells, diagonally in the upper half of the matrix, were filled and rest half was filled by their reciprocals. Then, the numerical values assigned in the cells were summed up column-wise and were recorded in the last row as sum.

The values in each cell in table 2 were first divided by their corresponding column sum and then results were recorded in the corresponding cells of table 3 . Finally, the mean values for each factor were calculated row-wise which represents the factor weight value. The priority of each factor based on earned weights in connection with landslides hazard in the study area is shown in the last column of table 3

Fig 2: Landslide Distribution Map 
Table 1: Number and density of landslide within the study area by VDC

\begin{tabular}{lccc}
\hline Name of VDC & Total Area $\left(\mathbf{k m}^{\mathbf{2}}\right)$ & No. of landslide & Landslide density $\left(\mathbf{N o .} / \mathbf{k m}^{\mathbf{2}}\right)$ \\
\hline Sarangkot & 13.88 & 9 & 0.65 \\
Kaskikot & 22.64 & 7 & 0.3 \\
\hline Study Area (whole) & $\mathbf{3 6 . 5 1}$ & $\mathbf{1 6}$ & $\mathbf{0 . 4 4}$ \\
\hline
\end{tabular}

Table 2: Matrix showing the couple comparison of the factors

\begin{tabular}{lcccccccc}
\hline Factor & Lithology & $\begin{array}{l}\text { Land } \\
\text { use }\end{array}$ & $\begin{array}{c}\text { Linement } \\
\text { and fault }\end{array}$ & Rainfall & Slope & Aspect & Road & Stream \\
\hline Lithology & 1 & 5 & 5 & 7 & 4 & 9 & 9 & 8 \\
Land use & $1 / 5$ & 1 & 3 & 3 & 5 & 8 & 7 & 1 \\
Linement and & $1 / 5$ & $1 / 3$ & 1 & 5 & 3 & 7 & 3 & 3 \\
fault & $1 / 7$ & $1 / 3$ & $1 / 5$ & 1 & 4 & 7 & 8 & 4 \\
Rainfall & $1 / 4$ & $1 / 5$ & $1 / 3$ & $1 / 4$ & 1 & 5 & 6 & 6 \\
Slope & $1 / 9$ & $1 / 7$ & $1 / 3$ & $1 / 8$ & $1 / 6$ & $1 / 5$ & 1 & 3 \\
Aspect & $1 / 9$ & $1 / 7$ & $1 / 3$ & $1 / 4$ & $1 / 6$ & $1 / 3$ & $1 / 3$ & 1 \\
Road & $1 / 8$ & 1 & $1 / 3$ & $1 / 4$ & $1 / 6$ & $1 / 3$ & $1 / 3$ & 1 \\
Stream & $\mathbf{2 . 1 4}$ & $\mathbf{8 . 1 3}$ & $\mathbf{1 0 . 3 4}$ & $\mathbf{1 6 . 7 6}$ & $\mathbf{1 7 . 5 3}$ & $\mathbf{3 7 . 5 3}$ & $\mathbf{3 9 . 3 3}$ & $\mathbf{2 9}$ \\
\hline Sum & & & & & & & & \\
\hline
\end{tabular}

\section{Weight values of the factor classes}

The weight values of the different factor classes were determined based on the percentages of area of each class of different factors covered by the landslide area. In lithology factor, the highest percentage of area of colluvial soil class was covered by the landslide area thus it was given highest factor class weight value of 100 , which when multiplied with the factor weight gave the actual weight value of 32.84 . Whereas the lowest percentages of area group class covered by the landslide area were given the lowest factor class weight value of 0 , which on multiplication with the factor weight yielded the actual weight value of 0 . Similarly, the weight values of the other factor classes were also determined and the details presented in table 4.

Table 3: Arithmetic mean method for calculating the factor weight values

\begin{tabular}{llllllllll}
\hline Factors & $\begin{array}{l}\text { Lithol- } \\
\text { ogy }\end{array}$ & $\begin{array}{l}\text { Land } \\
\text { use }\end{array}$ & $\begin{array}{l}\text { Linement } \\
\text { and fault }\end{array}$ & Rainfall & Slope & Aspect & Road & Stream & $\begin{array}{c}\text { Mean } \\
(\mathbf{W})\end{array}$ \\
\hline Lithology & 0.47 & 0.62 & 0.48 & 0.42 & 0.23 & 0.24 & 0.23 & 0.28 & 0.33 \\
Land use & 0.09 & 0.12 & 0.29 & 0.18 & 0.29 & 0.21 & 0.18 & 0.03 & 0.16 \\
$\begin{array}{l}\text { Linement } \\
\text { and fault }\end{array}$ & 0.09 & 0.04 & 0.10 & 0.30 & 0.17 & 0.19 & 0.08 & 0.10 & 0.12 \\
Rainfall & 0.07 & 0.04 & 0.02 & 0.06 & 0.23 & 0.19 & 0.20 & 0.14 & 0.11 \\
Slope & 0.12 & 0.03 & 0.03 & 0.02 & 0.06 & 0.13 & 0.15 & 0.21 & 0.18 \\
Aspect & 0.05 & 0.02 & 0.01 & 0.01 & 0.01 & 0.03 & 0.13 & 0.10 & 0.04 \\
Road & 0.05 & 0.02 & 0.03 & 0.01 & 0.01 & 0.01 & 0.03 & 0.10 & 0.03 \\
Stream & 0.06 & 0.12 & 0.03 & 0.02 & 0.01 & 0.01 & 0.01 & 0.03 & 0.03 \\
\hline
\end{tabular}




\section{Table 4: Details of the determination of the weight values of eight factors classes}

\begin{tabular}{|c|c|c|c|c|c|c|}
\hline S.No. & Factors Class & $\begin{array}{l}\text { Area of the class } \\
\text { (Grid) } \\
(1 \text { grid }=4 m * 4 m)\end{array}$ & $\begin{array}{c}\% \text { of LS } \\
\text { covered } \\
\text { area }\end{array}$ & $\begin{array}{c}\text { Weight by } \\
\% \text { of LS } \\
\text { covered area } \\
\text { (m) }\end{array}$ & $\begin{array}{c}\text { Factor } \\
\text { Weight } \\
\text { (w) }\end{array}$ & $\begin{array}{c}\text { Actual } \\
\text { Weight } \\
\text { (M) }\end{array}$ \\
\hline & Lithology & & & & & \\
\hline 1 & Residual soil & 91158 & 0 & 0 & 0.33 & 0 \\
\hline 2 & Talkot formation & 15168 & 0 & 0 & 0.33 & 0 \\
\hline 3 & Colluvial soil & 15379 & 0.63 & 100 & 0.33 & 32.84 \\
\hline 4 & Non active alluvial fan deposit & 47084 & 0 & 0 & 0.33 & 0 \\
\hline 5 & Ghachok formation & 5189 & 0 & 0 & 0.33 & 0 \\
\hline \multirow[t]{2}{*}{6} & Kuchha formation & 2108170 & 0.06 & 10.27 & 0.33 & 3.37 \\
\hline & Linement and fault & & & & & \\
\hline 1 & $0-800$ & 1232240 & 0.09 & 100 & 0.12 & 11.85 \\
\hline 2 & $800-1500$ & 434132 & 0.06 & 72.48 & 0.12 & 8.59 \\
\hline 3 & $1500-2300$ & 234019 & 0 & 0 & 0.12 & 0 \\
\hline 4 & $2300-3000$ & 289777 & 0 & 0 & 0.12 & 0 \\
\hline \multirow[t]{2}{*}{5} & $3000-3800$ & 91980 & 0 & 0 & 0.12 & 0 \\
\hline & River and stream & & & & & \\
\hline 1 & $0-370$ & 1727456 & 0.07 & 100 & 0.03 & 3.22 \\
\hline 2 & $370-730$ & 368101 & 0.02 & 21.5 & 0.03 & 0.69 \\
\hline 3 & $730-1100$ & 133668 & 0 & 0 & 0.03 & 0 \\
\hline 4 & $1100-1470$ & 48150 & 0 & 0 & 0.03 & 0 \\
\hline \multirow[t]{2}{*}{5} & $1470-1830$ & 4773 & 0 & 0 & 0.03 & 0 \\
\hline & Motorable road & & & & & \\
\hline 1 & $0-700$ & 1181755 & 0.1 & 100 & 0.03 & 2.81 \\
\hline 2 & $700-1500$ & 527182 & 0 & 3.92 & 0.03 & 0.11 \\
\hline 3 & $1500-2200$ & 296092 & 0.04 & 41.17 & 0.03 & 1.16 \\
\hline 4 & $2200-3000$ & 238193 & 0 & 0 & 0.03 & 0 \\
\hline \multirow[t]{2}{*}{5} & $3000-3700$ & 38926 & 0 & 0 & 0.03 & 0 \\
\hline & Slope & & & & & \\
\hline 1 & $<10$ & 834770 & 0.04 & 17.72 & 0.08 & 1.45 \\
\hline 2 & $10-30$ & 1269824 & 0.04 & 18.69 & 0.08 & 1.53 \\
\hline \multirow[t]{2}{*}{3} & $30<$ & 177554 & 0.24 & 100 & 0.08 & 8.2 \\
\hline & Aspect & & & & & \\
\hline 1 & North & 152515 & 0 & 0 & 0.04 & 0 \\
\hline 2 & South & 342351 & 0.13 & 100 & 0.04 & 3.98 \\
\hline 3 & East & 1380999 & 0.04 & 28.84 & 0.04 & 1.15 \\
\hline \multirow[t]{2}{*}{4} & West & 406283 & 0.1 & 82.89 & 0.04 & 3.3 \\
\hline & Land use & & & & & \\
\hline 1 & Swampy land & 60370 & 0.03 & 34.46 & 0.16 & 5.35 \\
\hline 2 & Forest land & 1036814 & 0.05 & 48.15 & 0.16 & 7.47 \\
\hline 3 & Sediment and Boulder & 57950 & 0.02 & 17.09 & 0.16 & 2.65 \\
\hline 4 & Agriculture & 689417 & 0.1 & 100 & 0.16 & 15.51 \\
\hline 5 & Settlement & 422780 & 0.03 & 27.18 & 0.16 & 4.22 \\
\hline \multirow[t]{2}{*}{6} & Water bodies & 14817 & 0 & 0 & 0.16 & 0 \\
\hline & Rainfall & & & & & \\
\hline 1 & Paudur Station & 2282148 & 0.06 & 100 & 0.1 & 10.47 \\
\hline
\end{tabular}




\section{Triggering factors}

Kunchha formation soil class covered the highest percentage of landslide area i.e. approximately $98 \%$ of the total landslide area found in study area. It might be because the Kunchha formation soil constitutes (greenish - greyphyllite, argillaceous phyllites, gritty quartzitic phyllites) the weak rock type like conglomerates and the deposition of sand, silt and gravel which are of the recent origin (i.e. quaternary to recent) in comparison to other groups. Here $92 \%$ of rock types constitute the Kunchha formation soil followed by $0.04 \%$ of residual soil, so majority of study area is dominated by Kunchha formation (Fig. 3).

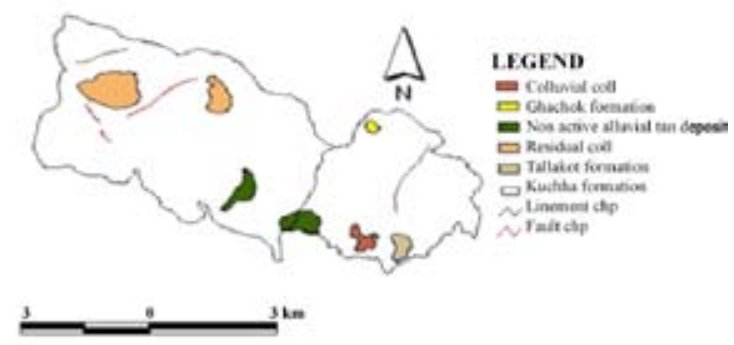

Fig. 3: Lithological map

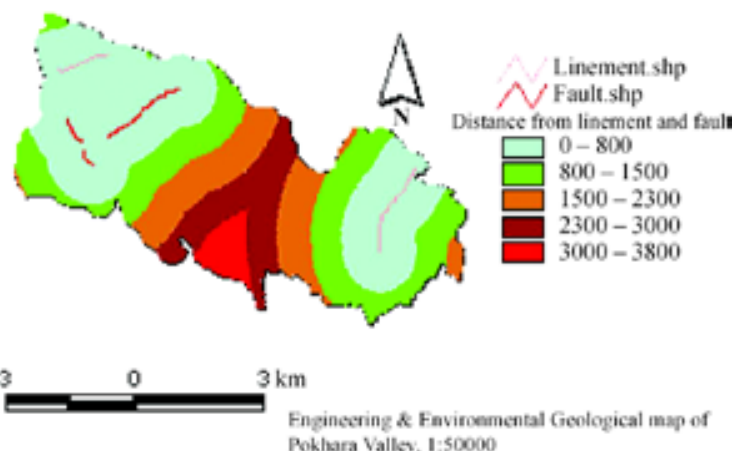

Fig. 4: Distance from linement and fault map

The study area was classified into 5 equal class interval of distance from linement and fault (Fig. 4). The classes closer to the linement and fault covered the higher percentages of landslide area compared to the classes far from the fault i.e. $80 \%$ of landslide area covered by the $0-800 \mathrm{~m}$ distance close to the linement and fault and $20 \%$ of landslide area covered by the $800-1500 \mathrm{~m}$. This might be because several faults occur in the study area and most of the streams run along these fault lines.
The study area was classified into 5 equal class interval of distance from river and stream (Fig. 5). The classes closer to the rivers and streams covered the higher percentages of landslide area compared to the classes far from the rivers and streams i.e. up to $0-370 \mathrm{~m}$ (i.e. $51 \%$ of the study area) distance from river and stream $99 \%$ of the landslide area was occupied. Rivers and streams promote mass movements by undercutting the base of the slopes and can also transport and deposit large volumes of debris. This is perhaps the reason why mass movements were very much influenced by the proximity to drainage lines, especially in case of debris slides.

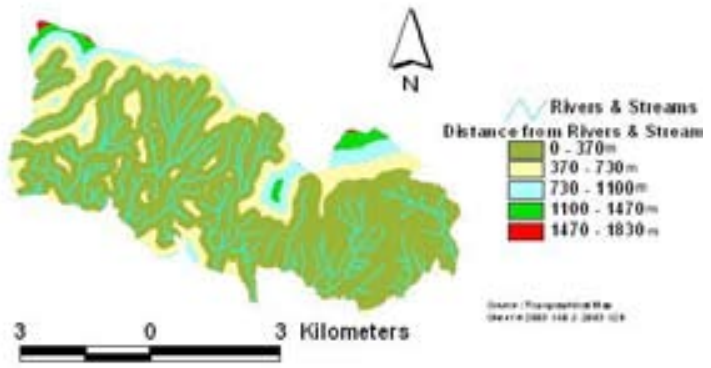

Fig. 5: Distance from rivers and stream map

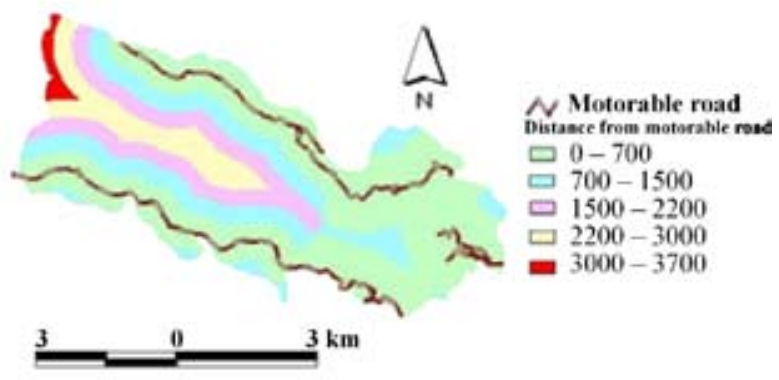

Fig. 6: Distance from motorable road map

The study area was classified into 5 equal class interval of distance from motorable road (Fig. 6). Factor classes closer to the motorable road covered the higher percentages of landslide area compared to the classes far from the motorable road. The distance $0-700 \mathrm{~m}$ (i.e. $51.7 \%$ of the study area) from the road covered $99 \%$ of the landslides area. This might be because with the increase in distance from the road tremor caused due to the vehicle movement goes on decreasing and at the same time presence of road triggers the landslide by under cutting of the slope. 
The study area was classified into 3 slope classes i.e. $0-10^{\circ}(36 \%$ of the study area $), 10-30^{\circ}(55 \%$ of the study area) and $>30^{\circ}(9 \%$ of the study area) (Fig. 7). It was found that $43 \%$ of landslide area was covered by $10-30^{\circ}$ slope class, $31 \%$ covered by $>30^{\circ}$ slope class and $26 \%$ of the landslide area covered by $<10^{\circ}$ slope class. In this study, the slope factor has been taken as an independent factor. But in practicality it is found very much associated with the dip of the rock beds. If the topographical slope direction and the dip direction of the rocks are in the same direction, then that particular area is considered most susceptible to the sliding and if the slope direction is not in direction of the dip then that area may be considered relatively stable and less susceptible to the sliding. Thus, it would have been very effective if the cumulative parameter representing the effect of these two factors i.e. slope and the dip could have been taken as the factor triggering the landslide occurrence.

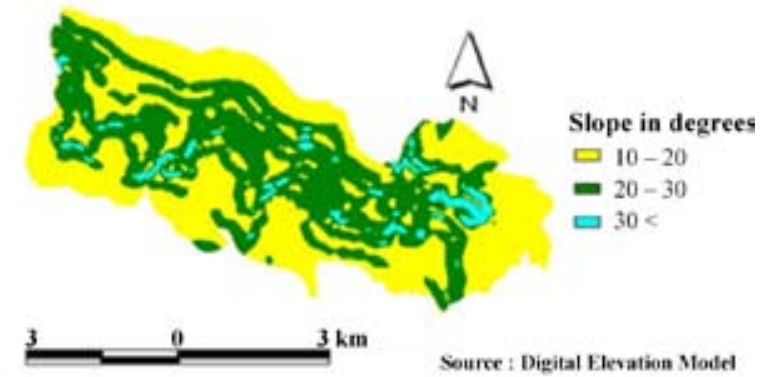

Fig. 7: Slope map

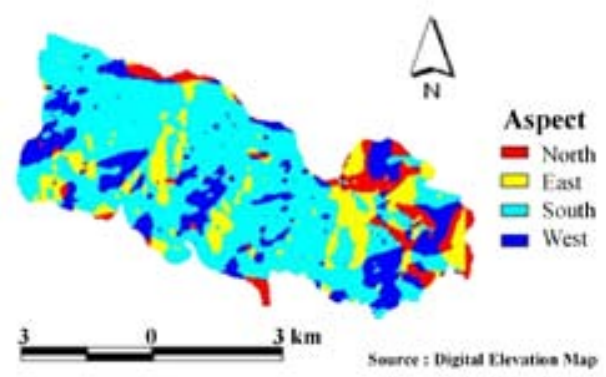

Fig. 8: Aspect map

In this case the study area was classified into 4 aspect classes i.e. north ( $6.6 \%$ of the study area), east $(60.5 \%$ of the study area), south $(15 \%$ of the study area) and west (17.9\% of the study area) (Fig. 8). South-facing slopes covered the highest percentage i.e. $37 \%$ of the landslide area, $36 \%$ covered by east-facing slopes and $27 \%$ by the west-facing slopes while north-facing slopes did not cover any of the landslide area in this study. This finding supports the finding of Shrestha et al. (2004) that the slides were dominant in the south-facing slopes and were least in case of north-facing slopes. This might be because of the drier environment, sparse vegetation and steeper slope gradients of southward areas.

Land use map of the study area as shown in figure 9 shows that agriculture land $(30.2 \%$ of the study area) covered the highest percentage i.e. $51 \%$ of landslide area and $33 \%$ of the landslide area covered by the forest land $(45.4 \%$ of the study area) while swampy land $(2.64 \%$ of the study area), settlement $(18 \%$ of the study area), Sandy/gravelly/boulders ( $2.5 \%$ of the study area) and water bodies ( $1.26 \%$ of the study area) covered the lowest percentage i.e. altogether $16 \%$ of landslide area. This might be because in the study area most of the agriculture practices are conducted without considering the soil conservation point of view and the lands are with high degrees of slope with very sparse randomly distributed shrubs and trees.

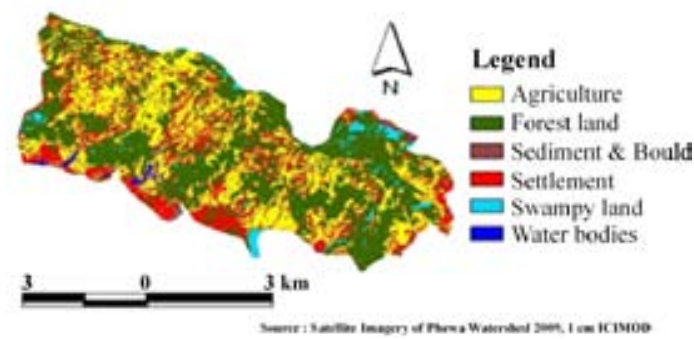

Fig. 9: Landuse map

For rainfall factor the whole study area was found to fall under Paudur Meteorological Station of Kaski. When the average monthly rainfall was computed from the monthly rainfall data of the station for the period of 10 years i.e. from 2000 to 2009 , it was found that the average monthly rainfall of Paudur Station was $410.38 \mathrm{~mm} / \mathrm{month}$. So the average monthly rainfall throughout the study area was assumed to be the same. Hence, the triggering effect of the rainfall factor was assumed to be uniform throughout the study area. In the study area maximum rainfall occurred during July and minimum rainfall fall occurred during the December (Fig. 10). 


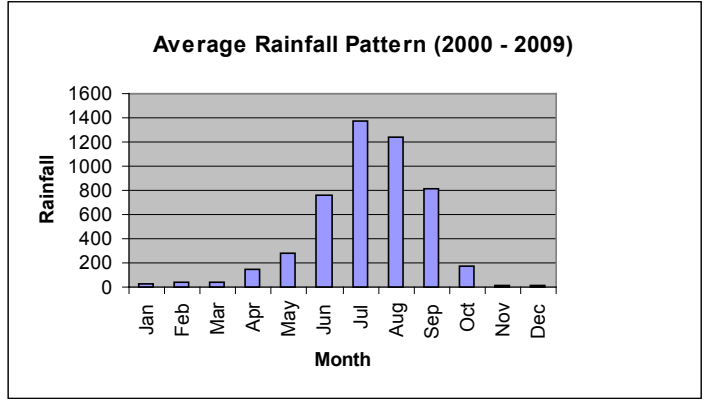

Fig.10: Average monthly rainfall

\section{Susceptibility coefficient of the study area}

The susceptibility coefficient of the study area derived from the combination of all eight factor maps employing the LHZ model shown in equation (i) was found to range from $20-100$ (Table 5). The area was classified into 5 relative hazard classes by equal interval classification method. Thus, the resulting LHZ map includes the 5 classes of susceptibility coefficient i.e. $20-36$ as very low hazard class, $36-52$ low hazard, $52-68$ moderate hazard, $68-84$ high hazard and $84-100$ very high hazard (Table 5). Majority of the study area $(54.92 \%)$ lied under moderate hazard zone followed by high hazard $(21.34 \%)$, very high hazard $(21.19 \%)$, low $(2.11 \%)$, and very low $(0.44 \%)$. The final LHZ map derived is presented in figure 11.

Table 5: Details of landslide hazard zonation map

\begin{tabular}{llll}
\hline $\begin{array}{l}\text { Hazard } \\
\text { Class }\end{array}$ & $\begin{array}{l}\text { Suscepti- } \\
\text { bility } \\
\text { Coefficient } \\
\text { (M) }\end{array}$ & $\begin{array}{l}\text { Area } \\
\text { (Grid) } \\
\text { (1grid= } \\
\mathbf{4 m * 4 m )}\end{array}$ & $\begin{array}{l}\text { \% of } \\
\text { area } \\
\text { occupied }\end{array}$ \\
\hline Very Low & $20-36$ & 10049 & 0.44 \\
Low & $36-52$ & 48172 & 2.11 \\
Moderate & $52-68$ & 1253324 & 54.92 \\
High & $68-84$ & 486910 & 21.34 \\
Very & $84-100$ & 483693 & 21.19 \\
High & & & \\
\hline
\end{tabular}

\section{Conclusion}

Landslides were mostly found in Sarangkot VDC. The overall landslide density in the study area was found to be 0.44 per $\mathrm{km}^{2}$. Sarangkot VDC had the highest landslide density of 0.65 per $\mathrm{km}^{2}$,

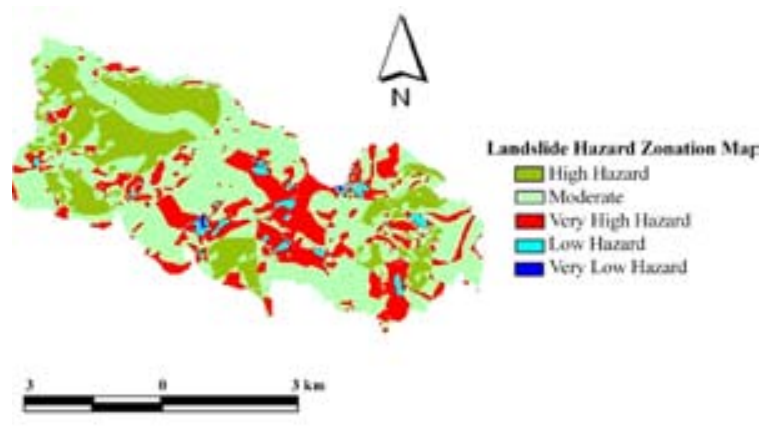

Fig. 11: Landslide hazard zonation map

thus making it the most hazard prone VDC. Main factors responsible for triggering the landslide in the study area are lithology (rock type), land use, presence of linement and fault, presence of motorable road, aspect, slope, rivers and streams and rainfall. Geologically, the high and very high hazard class areas are primarily associated with Kunchha formation. The majority of the study area $(54.92 \%)$ were under moderate hazard zone while only the small portion $(0.44 \%)$ of the area were under very low hazard zone. Very high hazardous zones were present in agriculture land, followed by forest land, settlements, swampy land and sediments and boulders. Most of the high and very high hazard class areas occupied the areas closer to the linear triggering factors like presence of linement and fault, motorable road, rivers and streams. The majority of the areas in the southward aspect belonged to the high and very high hazard classes.

It is expected that the results of this study, though limited to a preliminary and conceptual level, can provide decision-makers with useful insights into the trade-offs embedded in the complex landslide hazard zonation process.

\section{References}

Burrough, P. A. 1986. Principles of Geographic Information System for Land Resources Assessment. Clarendon Press, Oxford, UK.

Cruden, D. M. 1991. A simple definition of a landslide. IAEG Bulletin 43: 27-29.

DDC. 2010. Kaski District - An Introduction, District Development Committee (DDC), Pokhara, Nepal.

Esmali, A. 2003. Using GIS and RS in Mass Movements Hazard Zonation -A Case Study in Germichay Watershed, Ardebil, Iran. Ph. D. Thesis, Tehran University, Karaj, Iran. 
HMG/N, 1999. A Technical Guideline on Landslide Mitigation Work. Ministry of Water Resources, Kathmandu, Nepal.

JICA. 2001. Interim Report on the Development Study on the Environmental Preservation of Phewa Lake in Pokhara, Kathmandu, Nepal.

Lan, H. X., Zhou, C.H., Wang, L.J., Zhang, H.Y. and Li, R. H. 2004. Landslide hazard spatial analysis and prediction using GIS in the Xiaojiang Watershed, Yunnan, P. R. China. http://www.sciencedirect.com.

Maharjan, S. K. 2006. Investigation of Triggering Factors on Landslide Occurrence and Landslide Hazard Zonation - A GIS Based Approach. B. Sc. Thesis, Institute of Forestry, Pokhara, Kathmandu, Nepal.

Paudel, P. and Dhital, M. R. 2006, Landslide hazard and risk zonation of Thankot Chalnakhel area, central Nepal. Journal of Nepal Geological Society 31: 43-50.

Pradhan, B.K. 2007. Disaster Preparedness for Natural Hazards: Current Status in Nepal, ICIMOD, Kathmandu, Nepal.
Satty, T. L. 1980. The Analytical Hierarchy Process. McGraw-Hill; Cited in Ahp.pdf. New York, USA.

Shrestha, D. P., Zinck, J. A. and Ranst, E. V. 2004. Modeling Land Degradation in the Nepalese Himalaya. http://www.sciencedirect. com. Elsevier 57(2): 135-156. Amsterdam, Netherlands.

Tianchi, L. 1996. Landslide Hazard Mapping and Management in China. ICIMOD, Kathmandu, Nepal.

UNDRO. 1991. Mitigation Natural Disaster: Phenomena, Effects and Options - A Manual for Policy Makers and Planers Office of the United Nations Disaster Relief Coordinator, Geneva, Switzerland.

Upreti, B.N., Dhital, M.R. 1996. Landslide Studies and Management in Nepal. ICIMOD, Kathmandu, Nepal.

Varnes, D. J. 1978. Slope movement types and processes. In Landslide Analysis and Control (ed.) Clark, M. National Research Council, Transportation Board, Washington, D.C. USA, $11-33$. 